\title{
EFFECT OF SPERM INSEMINATION DURATION ON IN VITRO FERTILISATION (IVF) PERFORMANCE IN GOATS
}

\author{
Tan, W.L., Wan Khadijah, W.E. and Abdullah*, R.B.
}

Animal Biotechnology-Embryo Laboratory (ABEL), Institute of Biological Sciences, Faculty of Science, University of Malaya, 50603 Kuala Lumpur, Malaysia

*ramli@um.edu.my (Corresponding Author)

Received on $20^{\text {th }}$ July 2011 , accepted in revised form $24^{\text {th }}$ July 2011

\begin{abstract}
The objective of this study was to evaluate the effect of sperm insemination duration during in vitro fertilisation (IVF) on the cleavage rate of goat embryos. Goat oocytes were retrieved through the slicing of ovaries obtained from abattoir and laparoscopic oocyte pick-up (LOPU). For in vitro maturation (IVM), the collected cumulus oocyte complexes (COCs) were matured and then incubated overnight in $\mathrm{CO}_{2}$ $(5 \%)$ incubator at $38.5^{\circ} \mathrm{C}$ for $24-27 \mathrm{hr}$ (abattoir source) or 18-21 hr (LOPU source). Oocytes were partially denuded and co-incubated with post-thawed sperm with concentration of $1 \times 10^{6}$ sperm $/ \mathrm{ml}$. After 8-14 hr or 18 $24 \mathrm{hr}$ of insemination, in vitro culture (IVC) of presumptive zygotes were further incubated in $\mathrm{CO}_{2}(5 \%)$ incubator at $38.5^{\circ} \mathrm{C}$ for preimplantation embryonic development. The cleavage of the embryos was observed and recorded daily under inverted microscope. The fertilisation rate with insemination duration of 8-14 hr $(39.82 \%)$ was higher than that with $18-24 \mathrm{hr}(33.59 \%)$; however, there was no significant difference $(\mathrm{P}>0.05)$ between 2 groups of insemination durations. There was significant $(\mathrm{P}<0.05)$ decrease as the embryo developmental stages increased. Generally, the embryo developmental rates of all stages for insemination durations of $8-14 \mathrm{hr}$ were higher than that of $18-24 \mathrm{hr}$, which were 49.36 vs. $27.92 \% ; 33.77$ vs. $22.29 \%$; 7.32 vs. $2.08 \%$ and 0.56 vs. $0.00 \%$ for 2-, 4-, 8-cell and morula, respectively. In conclusion, shorter insemination duration may be needed to improve the IVF performance in goats.
\end{abstract}

\begin{abstract}
ABSTRAK Objektif kajian ini adalah untuk menilai kesan tempoh inseminasi sperma semasa persenyawaan in vitro (IVF) ke atas kadar pembelahan embrio kambing. Oosit kambing diperolehi melalui penghirisan ovari yang diperolehi dari rumah sembelihan dan laparoscopic oocyte pick-up (LOPU). Bagi pematangan in vitro (IVM), kompleks oosit kumulus (COCs) dimatangkan dan kemudian dieram semalaman dalam inkubator $\mathrm{CO}_{2}(5 \%)$ pada $38.5^{\circ} \mathrm{C}$ selama 24-27 jam (sumber rumah sembelihan) atau 18-21 jam (sumber LOPU). Oosit ditanggal kumulus sebahagiannya dan dieram bersama dengan sperma nyahsejukbeku dengan kepekatan $1 \times 10^{6}$ sperma/ml. Selepas 8-14 jam atau 18-24 jam diinseminasi, kultur in vitro (IVC) zigot andaian dieram seterusnya dalam inkubator $\mathrm{CO}_{2}(5 \%)$ pada $38.5^{\circ} \mathrm{C}$ bagi perkembangan embrio prapenempelan. Pembelahan embrio diperhati dan direkodkan setiap hari di bawah mikroskop inverted. Kadar persenyawaan dengan tempoh inseminasi 8-14 jam (39.82\%) adalah lebih tinggi daripada 18-24 jam (33.59\%); walau bagaimanapun, tiada perbezaan signifikan $(\mathrm{P}>0.05)$ ditemui antara 2 kumpulan tempoh inseminasi. Terdapat penurunan yang signifikan semasa setiap peningkatan peringkat perkembangan embrio. Secara amnya, kadar perkembangan embrio bagi semua peringkat perkembangan embrio untuk tempoh inseminasi 8-14 jam adalah lebih tinggi daripada $18-24$ jam, di mana 49.36 vs. $27.92 \%$; 33.77 vs. $22.29 \% ; 7.32$ vs. $2.08 \%$ and 0.56 vs. $0.00 \%$ bagi 2-, 4-, 8-sel dan morula, masing-masing. Kesimpulannya, kadar inseminasi yang lebih pendek mungkin diperlukan untuk memajukan prestasi IVF dalam kambing.
\end{abstract}

(Keywords: IVF, goat, insemination duration, embryo) 


\section{INTRODUCTION}

In vitro embryo production (IVP) technology has been widely used to increase the population of superior genetic merit of livestock animals including goats. To achieve success optimally, sufficient number of oocytes is the prerequisite for various reproductive techniques related to IVP procedures. In order to obtain abundant source of oocytes for large-scale production of embryos by IVP procedure, getting ovaries from abattoir is one of the ways [1]. However, in Malaysia, the number of female goats slaughtered is few and consequently it is quite difficult to carry out proper experiments in goat biotechnologies. Another source of oocytes could be alternatively obtained through laparoscopic oocyte pick-up (LOPU). It has been shown that the ovaries could be hyperstimulated several times and followed by aspiration of oocytes for various embryo techniques [2].

There are 3 main steps involved in the method of IVP of embryos, namely maturation of primary oocytes from large antral follicles, fertilisation of matured secondary oocytes with frozen-thawed semen and in vitro culture (IVC) of the putative embryos for up to 7 days until the formation of blastocysts. Conventionally, IVP in goats involves the superstimulation procedure in matured female animals either for flushing of embryos and oocytes or LOPU. Various gonadotrophins such as follicle stimulating hormone (FSH), pregnant mare's serum gonadotrophin (PMSG), equine chorionic gonadotrophin (eCG) and human chorionic gonadotrophin (hCG) have been introduced to the hormone regime for superovulation and superstimulation procedures.

A reduction of the period of sperm-oocyte exposure has been suggested to increase the incidence of monospermy [3, 4]. In fact, most of the current IVF systems use a 5-6 hr sperm-oocyte insemination duration [5, 6-9], compared to $12-18 \mathrm{hr}$ insemination duration used in the original porcine IVF systems [10-12]. Such information is not readily available in the literature and this issue is still controversial.

In the present study, we evaluated the efficiency of IVF performance for different insemination durations (co-incubation durations) during IVF procedure in goats.

\section{MATERIALS AND METHODS}

\section{Ovary source and animal preparation}

The sources of ovaries were from abattoir and LOPU. In order to prepare goats for LOPU, oestrus synchronisation and hyperstimulation of goats is necessary. Oestrous cycle of a donor goat was synchronised using insertion of a Controlled Intravaginal Drug Release device (CIDR, $0.3 \mathrm{~g}$ progesterone) into the vagina for 14 days (at 0900 hours on day 0) using a sterile CIDR applicator with water-based lubricant (K-Y Jelly). At $36 \mathrm{hr}$ prior to CIDR removal, a luteolytic treatment of Estrumate $^{\circledR}(125 \mu \mathrm{g}$ cloprostenol) was administered intramuscularly (i.m.; at 0900 hours on day 13) to regress corpus luteum that facilitated initiation of pro-oestrus and eventually resulted in oestrogen surge for the onset of heat (oestrus). PMSG (1500 IU) was administered (i.m.; at 1600 hours on day 14). Upon the removal of CIDR (at 2100 hours on day 14), Ovidrel $^{\circledR}$ (250 IU chorionic gonadotrophin) was administered (i.m.; at 2100 hours on day 14) to stimulate multiple follicular development prior to oocyte-retrieval surgery (at 0800 hours on day 17).

\section{Oocytes recovery}

For the abattoir source, the ovary was placed in a Petri dish $(90 \mathrm{~mm})$ containing TL-Hepes working solution $(5 \mathrm{ml})$ on a heating stage $\left(38.5^{\circ} \mathrm{C}\right)$. The ovary was held with the help of forceps and each ovary was sliced individually. Checker-board incisions were made along the whole ovarian surface using a quarter section of a stainless steel razor blade held with a sterile haemostat. The COCs in the Petri dish were then examined under a stereomicroscope.

For LOPU source, the donor goat was sedated and anaesthetised and a small incision was made on the disinfected abdominal area and a trocar connected to a $\mathrm{CO}_{2}$ tank via the $\mathrm{CO}_{2}$ insufflator was inserted into the incision to insufflate the abdominal cavity with $\mathrm{CO}_{2}$. Three small incisions $(3-5 \mathrm{~mm})$ were made once the peritoneum cavity was expanded. One of the incisions was made near the umbilicus to facilitate insertion of trocar for passing the light probe, one on the right side of lower-ventral abdomen to insert the trocar for passing the grasping forceps and one on the left side of lowerventral abdomen for passing oocyte retrieval needle.

Using the grasper, the uterine horns were gently manipulated to allow visualisation of each stimulated ovary. Once an ovary was identified, the ovarian ligament was grasped to stabilise the ovary for follicular puncture. The follicular contents were aspirated from all follicles visible on the surface of the ovaries by puncturing follicles with the aspiration needle. The collection tube containing 
aspirated fluid (3-5 ml) with COCs was dispensed into a sterile Petri dish $(90 \mathrm{~mm})$ for COCs searching under a stereomicroscope.

\section{In vitro maturation (IVM)}

A Petri dish $(35 \mathrm{~mm})$ with IVM droplets $(100 \mu \mathrm{l})$ which were overlaid with equilibrated silicone oil was prepared overnight. The dish was kept in $\mathrm{CO}_{2}$ incubator $(5 \%)$. Under the stereomicroscope, the COCs were identified and picked up, using a handcontrolled pipette. The COCs from LOPU were then washed in three droplets of flushing medium followed by three droplets of IVM medium, while COCs from ovary slicing were washed with TLHepes working solution followed by three droplets of IVM medium. The collected COCs were then matured and incubated overnight in $\mathrm{CO}_{2}(5 \%)$ incubator at $38.5^{\circ} \mathrm{C}$ for $24-27 \mathrm{hr}$ (abattoir source) or 18-21 hr (LOPU source).

\section{In vitro fertilisation (IVF)}

Oocytes were partially denuded by sucking in and out from the pipette. The oocytes left with one or two layers of cumulus cells were washed thrice with droplets of IVF medium $(100 \mu \mathrm{l})$ before being transferred to the insemination culture dish and kept in the $\mathrm{CO}_{2}$ incubator $(5 \%)$ to maintain its temperature $\left(38.5^{\circ} \mathrm{C}\right)$ and gas equilibration until required for insemination.

A frozen straw of goat sperm was pre-thawed at room temperature $\left(25^{\circ} \mathrm{C}, 1 \mathrm{~min}\right)$ followed by thawing in a water bath $\left(37^{\circ} \mathrm{C}, 3 \mathrm{~min}\right)$. Using a pair of sterile scissors, the straw was cut at both ends and the sperm was slowly released at the bottom of the swim-up tube $(15 \mathrm{ml})$. Without agitating the mixture of sperm and medium, the swim-up tube was carefully held at $60^{\circ}$ to the horizontal surface in the $\mathrm{CO}_{2}$ incubator $(5 \%)$ and incubated at $38.5^{\circ} \mathrm{C}$ in humidified air (45 min) to allow sperm swim-up. The upper layer of the medium containing highly motile sperm (sperm suspension) was aspirated (1 $\mathrm{ml}$ ) from the swim-up tube and placed in a sterile conical tube $(15 \mathrm{ml})$ and sperm-SOF medium $(2 \mathrm{ml})$ was added to the sperm suspension to make a total volume of $3 \mathrm{ml}$. With the tube tightly capped, the tube was centrifuged twice for $5 \min (200 \mathrm{x} g)$ and the supernatant was discarded. While conducting the assessment of sperm concentration, the capacitation-treated sperm were incubated in $\mathrm{CO}_{2}$ incubator $(5 \%)$. After the sperm concentration has been determined by haemacytometer, sufficient volume of sperm suspension was added to the fertilisation droplets $(30 \mu \mathrm{l})$ containing 5-10 matured oocytes to yield final concentration $1.0 \times 10^{6} \mathrm{sperm} / \mathrm{ml}$.

\section{In vitro culture (IVC)}

The dish containing IVC droplets under silicone oil were equilibrated overnight at $38.5^{\circ} \mathrm{C}$ in $\mathrm{CO}_{2}$ incubator $(5 \%)$. The culture medium used for in vitro embryo culture was KSOM. After 8-14 hr or 18-24 hr sperm insemination duration, all the presumptive zygotes were removed from the insemination droplets and washed, subsequently were transferred to new IVC droplets $(100 \mu \mathrm{l})$ for culture $\left(38.5^{\circ} \mathrm{C}, 5 \% \quad \mathrm{CO}_{2}\right)$. Each culture droplet $(100 \mu \mathrm{l})$ contained $5-10$ presumptive zygotes.

\section{Statistical analysis}

Data were analysed by analysis of variance (ANOVA) and Duncan's multiple range tests (DMRT), using the SPSS statistical software package version 17 . A probability of $\mathrm{P}<0.05$ was considered significant for all statistical tests. Values were presented as mean \pm SEM.

\section{RESULTS AND DISCUSSION}

The fertilisation rate of insemination duration of 8$14 \mathrm{hr}(39.82 \%)$ was relatively higher than that of $18-24 \mathrm{hr}(33.59 \%)$ (Table 1). The co-incubation of oocytes with sperm for $17 \mathrm{hr}$ was originally established for practical reasons and corresponds to the time for observation of pronuclei. As reported in goat IVF system [13], there was only $10.00 \%$ of oocytes fertilised following $1 \mathrm{hr}$ co-incubation with sperm; the cleavage rates were 71.00 vs. $78.00 \%$ (3 vs. $17 \mathrm{hr}$ co-incubation) and blastocyst rates were 50.00 vs. $53.00 \%$ (3- vs. $17 \mathrm{hr}$ co-incubation), respectively. The cleavage rates in their reports were relatively higher than that of the present study (49.36 vs. $29.32 \%$ for insemination durations of 8 14 vs. 18-24 hr, respectively) (Table 2). The $6 \mathrm{hr}$ delay in gamete interaction indicated that this duration is probably necessary for sperm to cross the cumulus or that differences in sperm capacitation kinetics exist between IVF systems (Figure 1(a-d)).

It was suggested that reducing the oocyte-sperm insemination duration lowers oocyte penetration and fertilisation during bovine IVF [14], but resulted in similar oocyte cleavage rates [15], and either similar [15] or reduced [16] rates of blastocyst formation. Shortening the gamete insemination duration during human IVF increases normal fertilisation [17, 18], embryo development [17, 19 and 20], increased embryo morphology [2023 ], implantation and pregnancy rates [21 and 23]. 
According to Marchal \& Matas, penetration of IVM porcine oocytes as well as polyspermic fertilisation occur as early as $2 \mathrm{hr}$ post-insemination. Moreover, it is known that the incidence of acrosome-reacted living sperm, under capacitating conditions, remains constant after 2, 4, and $6 \mathrm{hr}$ of co-incubation with oocytes (Vasquez, 1993). It was suggested that by reducing the sperm-oocyte insemination duration from $12-18$ to $8 \mathrm{hr}$ [27] as well as the removal of adherent sperm from the zona pellucida after 6-8 $\mathrm{hr}$ of insemination duration [28], decrease the incidence of polyspermy. Grupen et. al. 2000 proposed to decrease the exposure duration of matured oocytes to sperm from $5 \mathrm{hr}$ to $10 \mathrm{~min}$ and maintain the oocytes with the zonabound sperm in a fresh IVF medium drop without sperm for an additional $5 \mathrm{hr}$ incubation; and this modification of the IVF conditions resulted in a higher penetration rate $(57.00$ vs. $80.00 \%)$ and blastocyst development $(8.00$ vs. $30.00 \%)$ as compared to the conventional procedure of gametes co-incubated together for $5 \mathrm{hr}$. Frozen-thawed sperm cells generate increased amounts of reactive oxygen species (ROS) as by-products of metabolism and cell death [30, 31] which may be related to longer insemination duration. Several studies have shown that ROS plays an important role in mediating sperm-zona interactions as it increases DNA fragmentation [32], modifies the cytoskeleton [33], and produces a loss of fluidity, integrity and competence of the sperm membrane to participate in the membrane events associated with fertilisation [34-36].

Table 1. Fertilisation rate (\%, mean \pm SEM) of goat oocytes for different insemination durations in in vitro fertilisation

\begin{tabular}{ccc}
\hline Insemination duration & No. of matured oocytes & Fertilisation rate (n) \\
\hline $8-14 \mathrm{hr}$ & 134 & $39.82 \pm 8.18^{\mathrm{a}}$ \\
& & $(\mathrm{n}=68)$ \\
& & $33.59 \pm 10.97^{\mathrm{a}}$ \\
$18-24 \mathrm{hr}$ & 60 & $(\mathrm{n}=17)$ \\
& & \\
\hline
\end{tabular}

${ }^{a}$ Mean value within a column with same superscript was not significantly different $(\mathrm{P}>0.05)$

Table 2. Cleavage rate $(\%$, mean \pm SEM) of goat oocytes for different insemination durations in in vitro fertilisation

\begin{tabular}{lcccc}
\hline Insemination & \multicolumn{5}{c}{ Cleavage rate $(\mathrm{n})$} \\
duration & 2 -cell & 4 -cell & 8 -cell & Morula \\
\cline { 2 - 4 } & & & & \\
\hline $8-14 \mathrm{hr}$ & $49.36 \pm 10.41^{\mathrm{a}, \mathrm{z}}$ & $33.77 \pm 8.76^{\mathrm{a}, \mathrm{z}}$ & $7.32 \pm 5.06^{\mathrm{a}, \mathrm{y}}$ & $0.56 \pm 0.56^{\mathrm{a}, \mathrm{y}}$ \\
& $(\mathrm{n}=46)$ & $(\mathrm{n}=28)$ & $(\mathrm{n}=10)$ & $(\mathrm{n}=2)$ \\
$18-24 \mathrm{hr}$ & $27.92 \pm 10.87^{\mathrm{a}, \mathrm{z}}$ & $22.29 \pm 9.26^{\mathrm{a}, \mathrm{yz}}$ & $2.08 \pm 2.08^{\mathrm{a}, \mathrm{xy}}$ & $0.00 \pm 0.00^{\mathrm{a}, \mathrm{x}}$ \\
& $(\mathrm{n}=10)$ & $(\mathrm{n}=7)$ & $(\mathrm{n}=1)$ & $(\mathrm{n}=0)$ \\
\hline
\end{tabular}

${ }^{a}$ Mean value within a column with same superscript was not significantly different $(\mathrm{P}>0.05)$

${ }^{\mathrm{yz}}$ Mean values within a row with different superscripts were significantly different $(\mathrm{P}<0.05)$ 


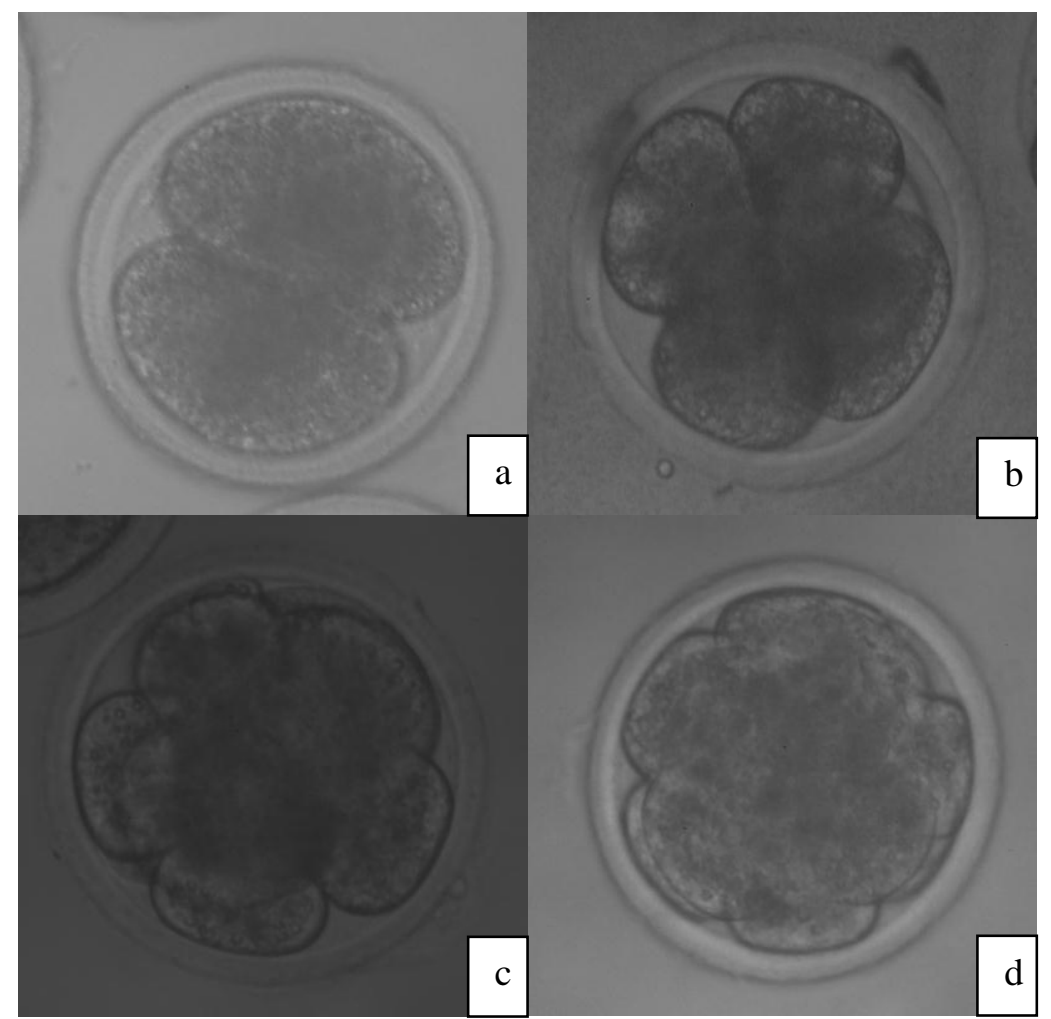

Figure 1(a-d): Embryos at 2- (a), 4- (b), 8-cell (c) and morula (d) obtained from goat IVF.

\section{CONCLUSION}

Many factors are involved in the IVF performance in goat including internal and external factors. This research indicates that insemination duration may play important role in the cleavage of goat embryo. It is suggested that shorter insemination durations of 8-14 hr may be better than that of $18-24 \mathrm{hr}$ as consistently shown in our data that the former was higher in the cleavage rates.

\section{ACKNOWLEDGEMENT}

The authors wish to thank ABEL members and staff of Institute of Biological Sciences (ISB) Mini Farm, University of Malaya (UM), abattoirs of Shah Alam and Senawang for their advices and assistance throughout this project. This project was funded by PPP Research Grant PS289/2010A (UM).

\section{REFERENCES}

1. Agrawal, K. P., Sharma T., Sexana C. and Sharma N. (1995). Chronology of first meiotic events of caprine oocytes matured in vitro. Indian Journal of Animal Sciences 65: 285 - 288.
2. Baldassarre, H., Rao K. M., Neveu N., Brochu E., Begin I., Behboodi E. and Hockley D. K. (2007). Laparoscopic ovum pick-up followed by in vitro embryo production for the reproductive rescue of aged goats of high genetic value. Reproduction, Fertility and Development 19: 612 - 616 .

3. Coy P., Martinez E., Ruiz S., Vazquez J. M., Roca J., Matas C. and Pellicer, M. T. (1993). In vitro fertilization of pig oocytes after different coincubation intervals. Theriogenology 39: 1201 - 1208.

4. Ocampo M. B., Ocampo L. C., Mori T., Ueda J. and Kanagawa H. (1994). Timing of sequential changes in chromosome configurations during the second meiotic division and cytoplasmic events of pig oocytes matured and fertilized in vitro. Animal Reproduction Science 34: 281288.

5. Abeydeera L. R. and Day B. N. (1997). Fertilization and subsequent development in vitro of pig oocytes inseminated in a 
modified Tris-buffered medium with frozen-thawed ejaculated spermatozoa. Biological Reproduction 57: 729 - 734

6. Abeydeera L. R., Wang W. H., Cantley T. C., Rieke A., Murphy C. N., Prather R. S. and Day B.N. (2000). Development and viability of pig oocytes matured in a protein-free medium containing epidermal growth factor. Theriogenology 54: 787 797.

7. Wang W. H., Abeydeera L. R., Han Y., Prather R. S., Day B. N. (1999). Morphologic evaluation and actin filament distribution in porcine embryos produced in vitro and in vivo. Biological Reproduction 60: 1020 - 1028.

8. Funahashi H., Mcintush E. W., Smith M. F., Day B. N. (1999). The presence of Tissue Inhibitor of Matrix Metalloproteinase-1 (TIMP-1) during meiosis improves porcine "oocyte competence" as determined by early embryonic development after in vitro fertilization. Journal Reproduction Development 45: 265 -271.

9. Gil M. A., Abeydeera L. R., Day B. N., Vazquez J. M., Roca J. and Martinez E. A. (2003). Effect of the volume of medium and number of oocytes during in vitro fertilization in embryo development in pigs. Theriogenology 60: 767 - 776.

10. Iritani A., Niwa K. and Imai H. (1978). Sperm penetration in vivo of pig follicular oocytes matured in culture. Journal Reproduction Fertility 54: 379 - 383.

11. Nagai T., Niwa K., Iritani A. and Leidl W. (1983). Improved rates of sperm penetration in vitro of pig follicular oocytes matured in culture. Japanese Journal of Fertility and Sterility 28: 313 318.

12. Toyoda Y., Itagaki Y., Minato Y. and Fukuda Y. (1984). Fertilization in vitro of pig eggs matured in vivo and in vitro. Proceeding of the 10th International Congress of Animal Reproduction AI 1: 395.

13. Cognie, Y., Baril, G., Poulin, N. and Mermillod, P. (2003). Current status of embryo technologies in sheep and goat. Theriogenology 59: 171 - 188.

14. Dode M. A. N., Rodovalho N. C., Ueno V. G. and Fernandes C. E. (2002). The effect of sperm preparation and co-incubation time on in vitro fertilization of bos indicus oocytes. Animal Reproduction Science 69: 15-23.

15. Gomez E. and Diez C. (2000). Spermatozoa affecting bovine embryo development in vitro attach to matured cumulus oocyte complexes within two hours of co-culture. Theriogenology 53: 421 [abstract].

16. Enright B. P, Lonergan P.,Ward F. A, Fair T. and Boland M. (2000). Effect of duration of maturation, duration of gamete coincubation and sperm concentration on cleavage and blastocyst development from cattle oocytes. Theriogenology 53: 419 [abstract].

17. Gianaroli L., Fiorentino A., Magli M.C., Ferraretti A.P. and Montanaro N. (1996). Prolonged sperm-oocyte exposure and high sperm concentration affect human embryo viability and pregnancy rate. Human Reproduction 11: 2507 - 2511.

18. Hyun C. S., Lee S. W., Yoon S. H., Son W. Y., Park S. P. and Lim J. H. (2000). Effect of short-time exposure of sperm on the fertilization parameters. Fertility and Sterility 74: 3491 [abstract].

19. Gianaroli L., Magli M. C., Ferraretti A. P., Fiorentino A., Tosti E., Panzella $\mathrm{S}$ and Dale B. (1996). Reducing the time of sperm oocyte interaction in human in vitro fertilization improves the implantation rate. Human Reproduction 11: 166 - 171.

20. Lin S. P., Lee R. K., Su J. T., Lin M. H. and Hwu Y. M. (2000). The effects of brief gamete co-incubation in human in vitro fertilization. J Assist Reprod Gen 17: 344 - 348 .

21. Dirnfeld M., Bider D., Koifman M., Calderon I. and Abramovici H. (1999). Shortened exposure of oocytes to spermatozoa improves in vitro fertilization outcome: a prospective, randomised, controlled study. Human Reproduction 14: 2562 - 2564. 
22. Quinn P., Michael L. L., Minh H., Bastuba M., Hendee F. and Brody S. A. (1998). Confirmation of the beneficial effects of brief co-incubation of gametes in human in vitro fertilization. Fertility and Sterility 69: 399 - 402.

23. Kattera S. and Chen C. (2003). Short coincubation of gametes in in vitro fertilization improves implantation and pregnancy rates: a prospective, randomised, controlled study. Fertility and Sterility 80: 1017 - 1021.

24. Marchal R., Pelaez J., Terqui M. and Mermillod P. (2002). Effect of sperm survival and CTC staining pattern on in vitro fertilization of porcine oocytes. Theriogenology 57: 1917 - 1927.

25. Matas C., Coy P., Romar R., Marco M., Gadea J. and Ruiz S. (2003). Effect of sperm preparation method on in vitro fertilization in pigs. Reproduction 125: $133-141$.

26. Vazquez J. M., Martinez E., Roca J., Coy P. and Pastor L. M. (1993). Acrosome reaction of boar spermatozoa in homologous in vitro fertilization. Molecular Reproduction and Development 36: 84 - 88.

27. Cheng W. T. K., Polge C. and Moor R. M. (1986). In vitro fertilization of pig and sheep oocytes. Theriogenology 25: 146.

28. Mattioli M., Bacci M. L., Galeati G. and Seren E. (1989). Developmental competence of pig oocytes matured and fertilized in vitro. Theriogenology 31: $1201-1207$.

29. Grupen C. G. and Nottle M. B. (2000). A simple modification of the in vitro fertilization procedure. Theriogenology 53: 422 .

30. Kessopolou E., Tomlinson J. J., Barrat C. L. R, Bolton A. E. and Cooke I. D. (1992). Origin of reactive oxygen species in human semen: spermatozoa or leucocytes? Journal Reproduction Fertility 94: 463470.

31. Jones R., Mann T. and Sherins R. J. (1979). Peroxidative breakdown of phospholipids in human spermatozoa: spermicidal effects of fatty acid peroxides and protective action of seminal plasma. Fertility and Sterility 31:531 - 537.

32. Lopes S., Jurisicova A., Sun J. G. and Casper R. F. (1998). Reactive oxygen species: potential cause for DNA fragmentation in human spermatozoa. Human Reproduction 13: 896 - 900.

33. Hindshaw D. B., Sklar L. A. and Bohl B. (1986). Cytoskeletal and morphologic impact of cellular oxidant injury. Am Journal Pathology 123: 454 - 464.

34. Aitken R. J. (1994). A free radical theory of male infertility. Reprod Fertil Dev 6: 19 $-24$.

35. Alvarez J. G. and Storey B. T. (1995). Differential incorporation of fatty acids into and peroxidative loss of fatty acids from phospholipids of human spermatozoa. Molecular Reproduction and Development 42: 334 -336.

36. Mammoto A., Masumoto N., Tahara M., Ikebuchi Y., Ohmichi M., Tasaka K. and Miyake A. (1996). Reactive oxygen species block sperm-egg fusion via oxidation of sperm sulfhydryl proteins in mice. Biological Reproduction 55: 1063 1068. 